University of Nebraska - Lincoln

DigitalCommons@University of Nebraska - Lincoln

Faculty Publications: Department of Entomology

Entomology, Department of

1990

\title{
Modification of the Effect of Bacillus thuringiensis on Sunflower Moth (Lepidoptera: Pyralidae) by Dietary Phenols
}

Gary J. Brewer

University of Nebraska-Lincoln, gbrewer2@unl.edu

Marc D. Anderson

North Dakota State University

Follow this and additional works at: https://digitalcommons.unl.edu/entomologyfacpub

Part of the Entomology Commons

Brewer, Gary J. and Anderson, Marc D., "Modification of the Effect of Bacillus thuringiensis on Sunflower Moth (Lepidoptera: Pyralidae) by Dietary Phenols" (1990). Faculty Publications: Department of Entomology. 228.

https://digitalcommons.unl.edu/entomologyfacpub/228

This Article is brought to you for free and open access by the Entomology, Department of at DigitalCommons@University of Nebraska - Lincoln. It has been accepted for inclusion in Faculty Publications: Department of Entomology by an authorized administrator of DigitalCommons@University of Nebraska - Lincoln. 


\title{
Modification of the Effect of Bacillus thuringiensis on Sunflower Moth (Lepidoptera: Pyralidae) by Dietary Phenols
}

\author{
GARY J. BREWER AND MARC D. ANDERSON \\ Department of Entomology, North Dakota State University, \\ Fargo, North Dakota 58105
}

\begin{abstract}
J. Econ. Entomol. 83(6): 2219-2224 (1990)
ABSTRACT The sunflower moth, Homoeosoma electellum (Hulst), a major pest of sunflower (Helianthus annuus L.), is susceptible to Bacillus thuringiensis Berliner, but field control has been inconsistent. Our study was done to determine whether phenolics in damaged sunflower tissue are in a conjugated or free form and whether they influence the toxicity of $B$. thuringiensis to the sunflower moth. Larvae fed diets containing $B$. thuringiensis had reduced survival and growth. The $\mathrm{LD}_{50}$ of $B$. thuringiensis was 52 international units of potency per gram of diet. Phenolic acids are general biocides. They were found in sunflower hybrids largely in the free (nonconjugated) form after tissue injury. The phenolics were probably converted from the conjugated form to the free form after release of glycosidases. By themselves and at the doses tested, specific phenolic acids did not affect sunflower moth survival and growth. When cinnamic or p-coumaric acids were combined with B. thuringiensis in artificial diet, growth (measured as width of sunflower moth head capsules) of larvae was reduced compared with that of larvae fed diets containing $B$. thuringiensis. High phenolic sunflower might increase the effectiveness of $B$. thuringiensis as an agent for sunflower moth control.
\end{abstract}

KEY WORDS Insecta, Homoeosoma electellum, Helianthus annuus, phenolic acids

SUNFLOWER (Helianthus annuus L.), a major oilseed crop, is attacked by numerous insect pests in its native habitat (North America). The sunflower moth, Homoeosoma electellum (Hulst), is found throughout most of North America and causes economic loss in sunflower (Schulz 1978).

Although resistance to the sunflower moth has been identified (see review by Rogers 1980), plant resistance has not been used effectively as a management tactic. As a result, control of the sunflower moth has relied on cultural and chemical means. Efforts to develop germplasm resistant to the sunflower moth are continuing and other methods of biological control are being evaluated. One such method is the use of Bacillus thuringiensis Berliner, a microbial insecticide with strains specific to Lepidoptera.

The sunflower moth is susceptible to $B$. thuringiensis in the laboratory (Lidstone et al. 1985) but results of field trials have been contradictory. Carlson (1975) did not find that B. thuringiensis effectively controlled the sunflower moth. However, Chandler \& Heilman (1982) and Rogers et al. (1984) reported that $B$. thuringiensis significantly reduced populations of the sunflower moth in the field.

Interactions between plants, insects, and entomopathic microbes are largely governed by plant allelochemicals (Berenbaum 1988). Most plant allelochemicals are general biocides: if the entomopathic microbe is more sensitive than the insect to the allelochemical, then pathogenesis will be reduced (Berenbaum 1988). Merdan et al. (1975) found that the natural mortality of Spodoptera littoralis (Boisduval), S. exigua (Hübner), Pieris rapae (L.), and Bombyx mori (L.) was not affected by feeding on foliage of different plant species (some with natural antibacterial substances and some without). However, they found that mortality caused by $B$. thuringiensis was reduced when larvae were fed foliage containing antibacterial substances. Koike et al. (1979) demonstrated that dietary caffeic acid reduces susceptibility of silkworm (B. mori) larvae to pathogenic Streptococcus.

Berenbaum (1988) also stated that if the microbe is less sensitive than the insect to plant allelochemicals, toxicity will be increased. An allelochemical that degrades the midgut wall is obviously detrimental to an insect ingesting it and may provide access for bacteria to the insect hemocoel. Lindroth \& Peterson (1988) reported that some plant phenols cause midgut lesions in the southern armyworm, S. eridania (Cramer). Other plant compounds such as tannin (Steinly \& Berenbaum 1985) and cyanide (Brattsten et al. 1983) also cause midgut lesions in lepidopteran larvae. A similar mode of action is used by some pathogenic bacteria that have a toxin that degrades the insect midgut and permits entrance of bacteria to the hemocoel (Bucher 1960).

The effectiveness of $B$. thuringiensis in controlling the sunflower moth may be affected by sunflower phenolics. Leung et al. (1981) found that chlorogenic acid was the major free phenolic and that caffeic acid predominated in acid and alkaline hydrolysis of seven sunflower cultivars. In addition to the principal phenolics, they found p-hydroxy- 
benzoic, p-coumaric, cinnamic, m-hydroxybenzoic, vanillic, and syringic acids in lesser amounts. Dabrowski \& Sosulski (1984) reported that defatted sunflower achenes contain nearly $1.0 \%$ caffeic acid and up to $2.85 \%$ by weight of chlorogenic acid, a caffeic acid ester. They also found small amounts of p-hydroxybenzoic, vanillic, syringic, p-coumaric, and ferulic acids.

In plants, most phenolics are stored as glycosides (sugar conjugates). Compared with free phenolics, phenolic glycosides have reduced toxicity and improved water solubility (Harborne 1979). However, phenolic glycosides are subject to hydrolysis by plant glycosidases to form the free phenolic (Hosel 1981). Glycosidases may also have a role in plant defense by converting the relatively inert phenolic glycosides to their toxic, free forms after tissue injury or herbivory. In sweet clover leaves, a conversion of bound coumarin to free coumarin occurs in injured tissue (Kosuge 1961). A similar liberation of hydrogen cyanide from cyanogenic glycosides occurs after plant tissue is damaged (Bell 1981).

Our first objective was to determine whether phenolics in damaged sunflower tissue are in the free or conjugated form. Our second objective was to test the susceptibility of the sunflower moth to $B$. thuringiensis and to determine whether control of sunflower moth with $B$. thuringiensis is enhanced by phenolic acids.

\section{Materials and Methods}

Phenolic Acid Determination. Nine sunflower hybrids were grown in the greenhouse for phenolic analysis. The hybrids used were Northrup King '212,' Interstate ' 894 ,' Seed Tec ' 315 ' and ' 316 ,' Dahlgren '643-7E' and '647-7E,' and three hybrids from Agriculture Canada '83-202,' '84-108,' and '85-346.' Ten grams of head (capitulum) tissue at the early bud stage was taken from three heads of each hybrid, combined, and ground for extraction in methanol/acetone $(1: 1)$ according to the procedures of Krygier et al. (1982). Approximately 20 min elapsed between removal of the head tissue and initiation of the extraction procedure. Ten milliliters of p-coumaric acid $(1.0 \mathrm{mg} / \mathrm{ml})$ was added to two extra samples as an internal standard to test the efficiency of extractions. Phenolics were detected nonspecifically by the method of Lowry et al. (1951). We did not attempt to identify specific phenolics. Results for all hybrids were pooled to give average levels of free, conjugated, and total phenolics in hybrid sunflower.

Bioassays. All bioassays were done in a growth chamber maintained at $27.8 \pm 1.1^{\circ} \mathrm{C}$ and a photoperiod of 12:12 (L:D). Single neonates were placed in a $180-\mathrm{ml}$ plastic container with a 2 -g block of diet that included the appropriate combination of $B$. thuringiensis, or phenol, or both. Data were collected on day 7 .
Table 1. Overall mean free, conjugated, and total phenolic concentrations in hybrid sunflower

\begin{tabular}{lcc}
\hline \hline & \multicolumn{2}{c}{ Phenolic concn., mg/g } \\
\cline { 2 - 3 } & $\bar{x}(\mathrm{SD})^{b}$ & Range \\
\hline Free & $0.702(0.207)$ & $1.115-0.455$ \\
Conjugated & $0.168(0.146)$ & $0.410-0.035$ \\
Total & $0.870(0.225)$ & $1.250-0.630$ \\
\hline
\end{tabular}

a Internal standard calculations reveal that the recovery of phenolics was $67.5 \%$.

${ }^{b}$ Mean for nine hybrids.

Bacillus thuringiensis Assay. The response of sunflower moth larvae to ingestion of $B$. thuringiensis was tested. The $B$. thuringiensis (Dipel WP, Abbott Laboratories, Chicago) used was a commercial preparation containing delta endotoxin and live spores and having 16,000 international units (IU) per mg. B. thuringiensis was incorporated into diet (prepared as described by Vanderzant et al. $1962)$ and was tested with 619 larvae. Six doses (5, $10,20,30,60$, and $120 \mathrm{IU} / \mathrm{g}$ wet diet) were used. Controls consisted of 140 larvae fed standard diet (without $B$. thuringiensis). Probit regression of the dose-mortality response for $B$. thuringiensis was estimated with POLO-PC (LeOra Software 1987). Head capsule width of larvae surviving to day 7 was measured with a dissecting microscope equipped with digital micrometers (Mitutoyo Manufacturing Company, Tokyo). Head capsule widths were evaluated with analysis of variance and means were separated with Tukey's procedure (PROG GLM, SAS Institute 1985, 433-506).

Phenolic Acid and B. thuringiensis Assays. Two types of test diets were used in bioassay. The first diet type was treated with phenolic acids to determine their effect on the sunflower moth. Based on the results of the phenolic acid determination, free rather than conjugated phenolic acids were used. Four commercially available phenolic acids, caffeic and chlorogenic acids (the predominant sunflower phenolic acids; Dabrowski \& Sosulski [1984]) and cinnamic and p-coumaric acids (minor sunflower phenols), were incorporated into diet. Diets contained phenol at $0.01 \%$ (wet weight), a concentration below which detectable effects on the sunflower moth were apparent (G.J.B., unpublished data) but within the range of phenols in sunflower (Sabir et al. 1974). To determine if dietary phenols affect toxicity of $B$. thuringiensis, phenolic acids and $B$. thuringiensis were incorported into the second type of diet. The diets contained phenol at $0.01 \%$ (wet weight) and $B$. thuringiensis at $20 \mathrm{IU} / \mathrm{g}$ wet diet. A dose of $20 \mathrm{IU}$ of $B$. thuringiensis is sufficient to reduce growth of sunflower moth but allows most of the larvae to survive.

Two types of controls were used. In one, larvae were fed standard (control) diet; in the other, larvae were fed diet treated with $B$. thuringiensis at a dose of $20 \mathrm{IU} / \mathrm{g}$ wet diet. Testing was done over 


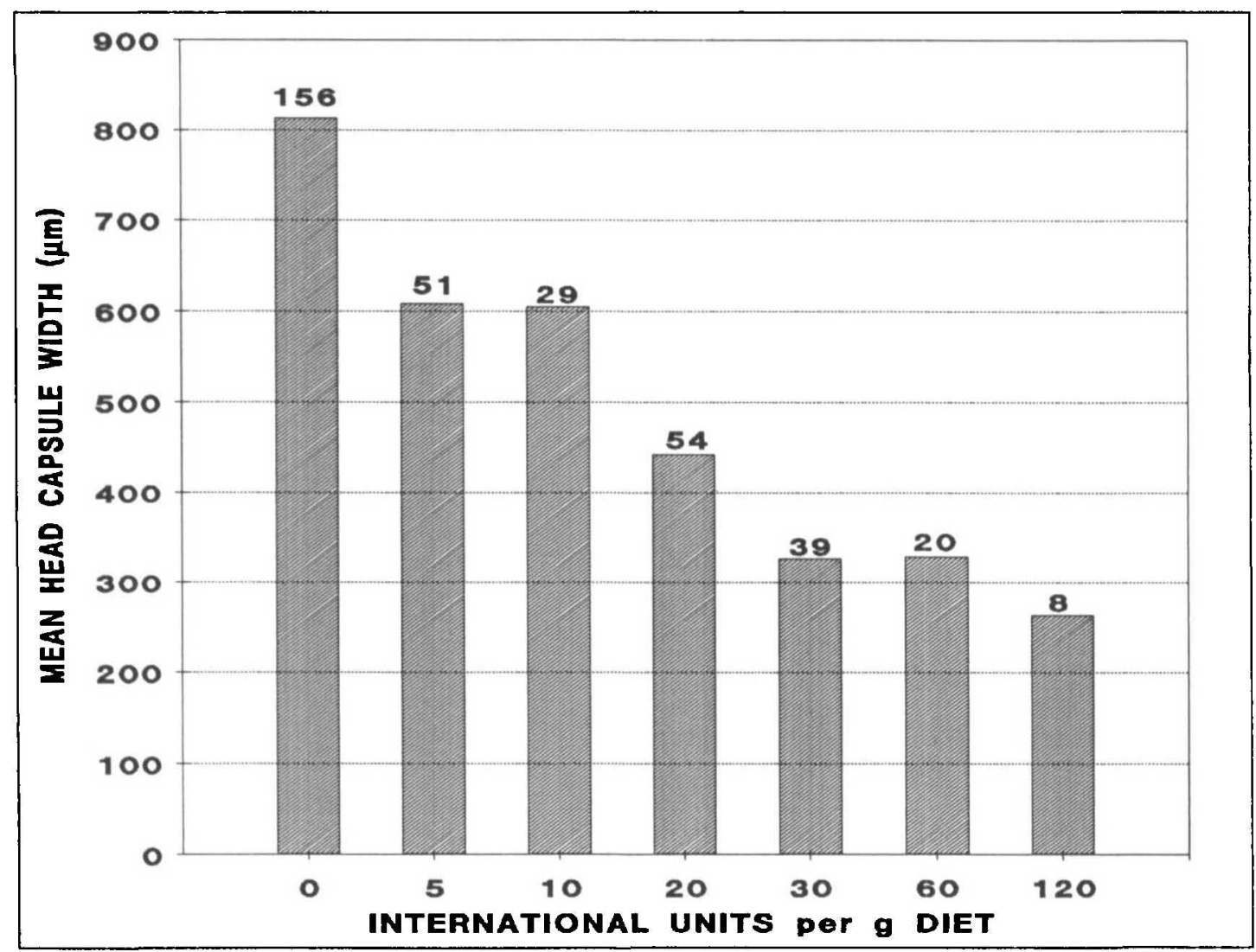

Fig. 1. Effect of B. thuringiensis on head capsule width of sunflower moth at day 7. Number of larvae measured listed above bars. Means of all treatments were significantly smaller than the control mean $(P=0.05$; Tukey's studentized range test, $q=4.194$ [SAS Institute 1985]).

time with different test and standard diets. If mortality of larvae fed standard diet was $>5 \%$, the data for that test were discarded. Otherwise, the results of tests were pooled, and total larval mortality and head capsule width were subjected to statistical analysis. Each treatment was replicated 20 times except that with caffeic acid, which was replicated 40 times. Because test results were pooled for statistical analysis, replications for the control diets (control and $B$. thuringiensis diets) were $>20$. $\chi^{2}$ tests were used to compare mortality of larvae fed test diets with mortality of larvae fed check diets. Mortality data are presented as percentage of surviving larvae. Because of mortality, the number of larvae measured for head capsule width was less than number of larvae originally placed on diet. Analysis of variance and Tukey's procedure (SAS Institute 1985) were used to analyze the effect of dietary phenols on width of larval head capsules.

\section{Results}

Phenolic Acid Determination. Overall mean levels of free and conjugated phenolic acids for sunflower hybrids are given in Table 1. Levels of free phenolic acids were much higher than levels of conjugated phenolics and constituted $>80 \%$ of the total phenolics.

Bacillus thuringiensis Assay. Mortality of sunHower moth increased with increasing dose of $B$. thuringiensis incorporated into the diet. $\mathrm{LD}_{10}, \mathrm{LD}_{50}$, and $\mathrm{LD}_{90}$ and their $0.95 \mathrm{CL}$ in terms of IUS of $B$. thuringiensis potency per gram wet diet were 4.6 (1.6-8.4), $51.8(36.4-77.8)$, and 586.3 (289.0-2120.0) $(n=619$, slope $\pm \mathrm{SE}=1.216 \pm 0.123)$. Head capsule width of larvae surviving to day 7 at the various treatment doses was generally inversely related to dose (Fig. 1). All larvae fed diets treated with $B$. thuringiensis had significantly ( $F=67.61$ $\mathrm{df}=6,350 ; P<0.001)$ smaller head capsules than larvae fed standard diet.

Phenolic Acid and $B$, thuringiensis Assays. Sunflower moth survival on phenolic acid diets was not significantly ( $\chi^{2}$ test, $P=0.05$ ) different from that of the control (Fig. 2). None of the phenol treatments significantly $(F=35.30 ; \mathrm{df}=9,316 ; P$ $<0.001$ ) affected larval growth, measured as head capsule width (Fig. 3).

More larvae survived on diets containing $B$. thuringiensis and caffeic or p-coumaric acid than on diets treated with $B$. thuringiensis. Compared with diet treated with $B$. thuringiensis, survival of lar- 


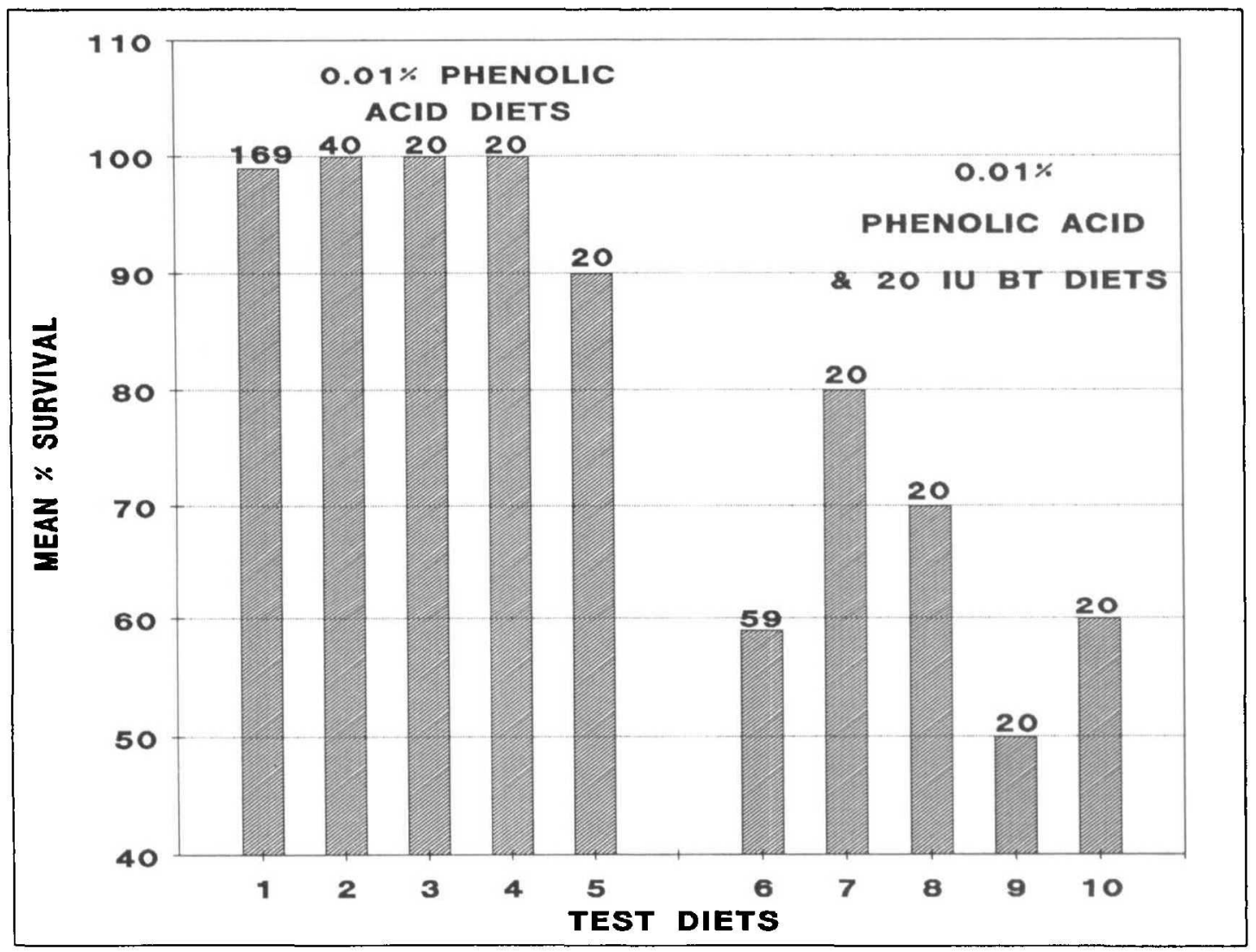

Fig. 2. Effect of phenol and B. thuringiensis (BT) on percentage of sunflower moth survival. Number of larvae tested listed above bars. Test diets: 1 , control; 2, caffeic; 3, p-coumaric; 4, cinnamic; 5 , chlorogenic; $6, \mathrm{BT} ; 7$, BT \& caffeic; 8, BT \& p-coumaric; 9, BT \& cinnamic; 10, BT \& chlorogenic acid diets. No means within diet groups were significantly different ( $P=0.05 ; \chi^{2}$ test).

vae was reduced on diet containing $B$. thuringiensis and cinnamic acid (Fig. 2).

Mean head capsule width of larvae fed diet containing $B$. thuringiensis and caffeic acid was greater than that of larvae fed diet treated with $B$. thuringiensis alone but the difference was not significant (Fig. 3). Larvae fed diets treated with B. thuringiensis and p-coumaric or cinnamic acid had significantly smaller head capsule widths compared with larvae fed diet treated with $B$. thuringiensis.

\section{Discussion}

Our results agree with those of Lidstone et al. (1985), who showed that the sunflower moth is susceptible to $B$. thuringiensis. Although not reported in the same units of measurements, their $\mathrm{LD}_{50}$ value (19.8 IU/ml incorporated diet) for second and third instars is less than what we estimated for first instars $\left\langle\mathrm{LD}_{50}=51.8 \mathrm{IU} / \mathrm{g}\right.$ incorporated diet). Their larvae were reared on a sunflower head, removed and placed on treated diet for bioassay, while we tested newly eclosed larvae that were placed directly on treated diet. Larvae may have been stressed when removed from the sunflower head or a diet of plant tissue may have increased their susceptibility to $B$. thuringiensis. Besides reduced larval survival, we observed reduced larval growth. Because paralysis of the gut wall and a cessation of feeding are common symptoms of toxicity of $B$. thuringiensis (Heimpel \& Angus 1959), reduced growth was expected.

Levels of free phenolics were unexpectedly high in mechanically damaged sunflower tissue. Although levels of free phenolic acid in sunflower may be higher than reported in the literature (Dabrowski \& Sosulski 1984), the conjugated form was probably converted to the free form. Conversion of the phenolic glycosides to free phenolics probably occurred, via glycosidases, during the time between removal of the head tissue (mechanical damage) and extraction. A similar conversion of conjugated phenolics to the free form in response to insect damage is likely. Larval feeding causes considerable tissue damage and probably results in increased levels of free phenolics in the damaged tissues. Because most phenolics in damaged sunHower tissue are in the free form, a chewing insect 


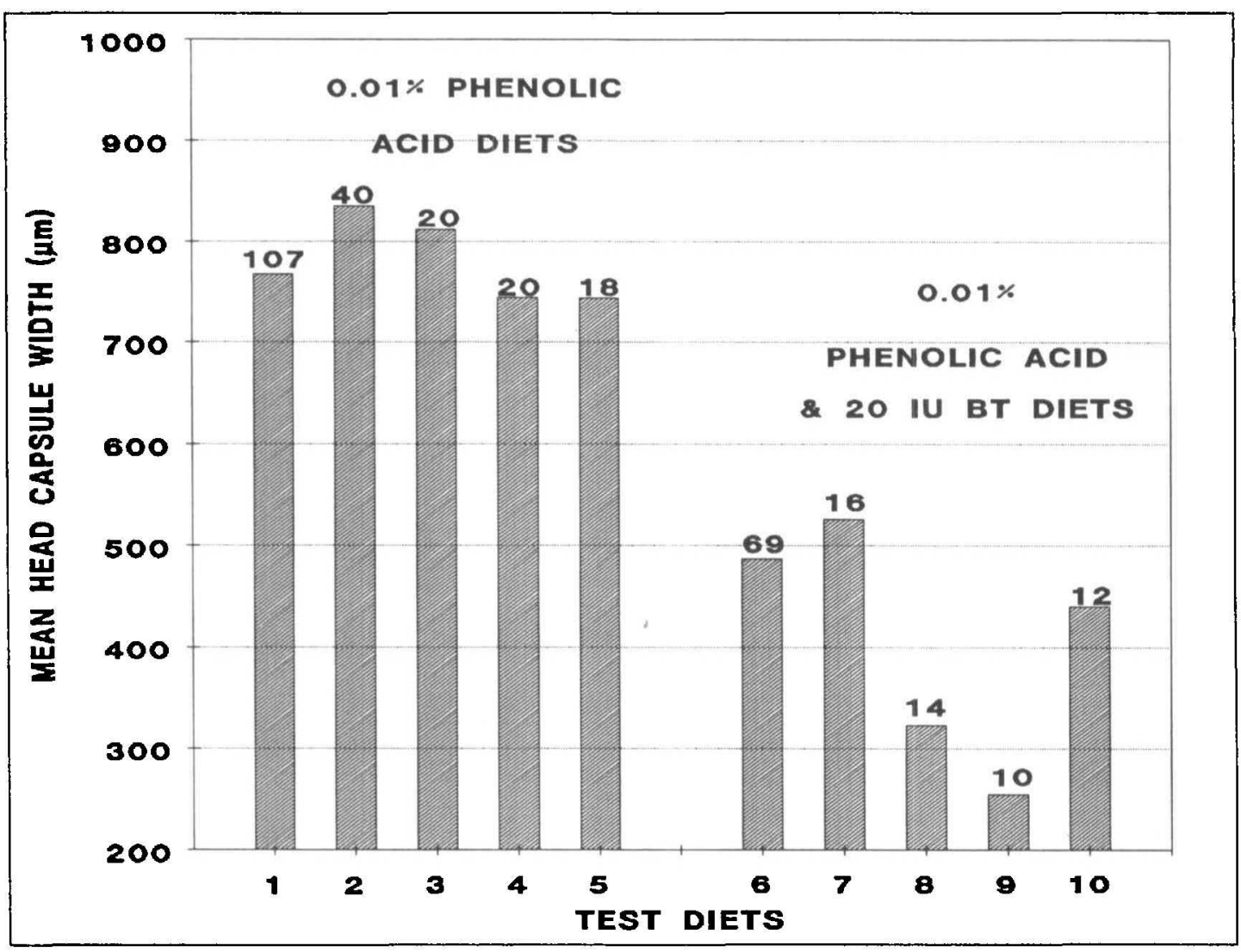

Fig. 3. Effect of phenol and B. thuringiensis (BT) on head capsule width of sunflower moth at day 7 . Number of larvae measured listed above bars. Test diets: 1 , control; 2, caffeic; 3, p-coumaric; 4, cinnamic; 5 , chlorogenic; 6, BT; 7, BT \& caffeic; 8, BT \& p-coumaric; 9, BT \& cinnamic; 10, BT \& chlorogenic acid diets. Means of all diets containing BT differed significantly from mean of control diets, no. 1. Means of diets containing BT and p-coumaric or cinnamic acid differed significantly from mean of diets with BT, no. $6(P=0.05$, Tukey's studentized range test, $q=4.506$ [SAS Institute 1985]).

feeding on sunflower tissue will ingest more free than conjugated phenolics.

The use of $B$. thuringiensis to protect sunflower from the sunflower moth and perhaps other lepidopteran pests may be enhanced by the host plant phenolics. Judicious selection of sunflower varieties high in particular combinations of phenolics (e.g., cinnamic and p-coumaric acids) could increase sunflower compatibility with $B$. thuringiensis. However, as suggested by data for interaction of $B$. thuringiensis and caffeic acid, some phenolics may suppress $B$. thuringiensis toxicity more than they inhibit the sunflower moth. Thus, the effect of phenolics on toxicity of $B$. thuringiensis to the sunflower moth should be tested further before sunflower selection criteria are established.

The increased toxicity in sunflower moth larvae exposed to $B$. thuringiensis when cinnamic or p-coumaric acid was present has implications for pest management. Sunflower high in phenolics, especially cinnamic and p-coumaric acid, may enhance the effectiveness of $B$. thuringiensis and permit lower rates of application. In sunflower genetically modified to produce the $B$. thuringiensis toxin, reduced rates of $B$. thuringiensis expression in high-phenolic sunflower could still provide control.

Plant pathologists and weed scientists are interested in high-phenolic sunflower to control sunflower pathogens (Bazzalo et al. 1985) and weed competitors (Lovett et al. 1982). Although natural levels of phenolics in sunflower may aid in inhibiting pathogens and weeds, by themselves, they probably would not affect the sunflower moth. However, if $B$. thuringiensis is present as a microbial insecticide or sunflower is genetically modified to produce the $B$. thuringiensis toxin, selection of sunflower high in some phenols may increase the effectiveness of the $B$. thuringiensis.

\section{Acknowledgment}

A portion of this report is part of a M.S. thesis (M.D.A.) submitted to North Dakota State University, Fargo. Partial funding was provided by CSRS cooperative agree- 
ment, 84-CRSR-2-2362. This is North Dakota Agricultural Experiment Station Journal Series 1828.

\section{References Cited}

Bazzalo, M. E., E. M. Heber, M. A. Del Pero Martinez \& O. H. Caso. 1985. Phenolic compounds in stems of sunflower plants inoculated with Sclerotinia sclerotiorum and their inhibitory effects on the fungus. Phytopathol. Z. 112(4): 322-332.

Bell, E. A. 1981. The physiological role(s) of secondary (natural) products, pp. 1-19. In E. E. Conn [ed.], The biochemistry of plants, vol. 7. Secondary plant products. Academic, New York.

Berenbaum, M. R. 1988. Allelochemicals in insectmicrobe-plant interactions; agents provocateurs in the coevolutionary arms race, pp. 97-123. In P. Barbosa \& D. K. Letourneau [eds.], Novel aspects of insectplant interactions. Wiley, New York.

Brattsten, L. B., J. H. Samuelina, K. Y. Long, S. A. Kincaid \& C. K. Evans. 1983. Cyanide as a feeding stimulant for the southern armyworm, Spodoptera eridania. Ecol. Entomol. 8(2): 125-132.

Bucher, G. E. 1960. Potential bacterial pathogens of insects and their characteristics. J. Insect Pathol. 2(2): 172-195.

Carlson, E. C. 1975. Pesticides for controlling sunHower moth larvae. Calif. Agric. 29 (May): 12-13.

Chandler, L. D. \& M. D. Heilman. 1982. Efficacy and phytotoxicity evaluations of microbial insecticides for control of the sunflower moth in South Texas. Texas Agriculture Experiment Station PR-4056, College Station.

Dabrowski, K. J. \& F. W. Sosulski. 1984. Composition of free and hydrolyzable phenolic acids in defatted flours of oilseeds. J. Agric. Food Chem. 32(1): $128-130$

Harborne, J. B. 1979. Variation in and functional significance of phenolic conjugation in plants, pp. 457-474. In T. Swain, J. B. Harborne \& C. F. Van Sumere [eds.], Recent advances in phytochemistry, vol. 12. Biochemistry of plant phenolics. Plenum, New York.

Heimpel, A. M. \& T. A. Angus. 1959. The site of action of the crystalliferous bacteria in Lepidopterous larvae. J. Insect. Pathol. 1(2): 152-170.

Hosel, W. 1981. Glycosylation and glycosidases, pp. 725-753. In E. E. Conn [ed.], The biochemistry of plants, vol. 7. Secondary plant products. Academic, New York.

Koike, S., T. Iizuka \& J. Mizutani. 1979. Determination of caffeic acid in digestive juice of silkworm larvae and its antibacterial activity against the pathogenic Streptococcus faecalis AD-4. Agric. Biol. Chem. 43(8): 1727-1731.

Kosuge, T. 1961. Studies on the identity of bound coumarin in sweet clover. Arch. Biochem. Biophys. 95(1): $211-218$.
Krygier, K., F. Sosulski \& L. Hogge. 1982. Free, esterified, and insoluble-bound phenolic acids. 1. Extraction and purification procedure. J. Agric. Food Chem. 30(2): 330-334.

LeOra Software. 1987. POLO-PC a users guide to probit or logit analysis. LeOra Software, Berkeley, Calif.

Leung, J., T. W. Fenton \& D. R. Clandinin. 1981. Phenolic components of sunflower flour. J. Food Sci. 46(5): 1386-1393.

Lidstone, R. G., D. W. Goerzen \& G. G. Khachatourians. 1985. A standardized bioassay for larval activity of Bacillus thuringiensis in sunflower moth Homoeosoma electellum (Lepidoptera: Phycitidae). Can. Entomol. 117(1): 15-22.

Lindroth, H. L. \& S. S. Peterson. 1988. Effects of plant phenols on performance of southern armyworm larvae. Oecologia (Berl.) 75(2): 185-189.

Lovett, J. V., S. A. Fraser \& A. M. Duffield. 1982. Allelopathic activity of cultivated sunflowers, pp. 198201. In Proceedings of the 10th International Sunflower Conference. Surfers Paradise, Australia. Australian Sunflower Association.

Lowry, O. H., N. J. Rosenbrough, A. L. Farr \& R. J. Randall. 1951. Protein measurement with the Folin phenol reagent. J. Biol. Chem. 193(1): 265-275.

Merdan, A., H. Abdel-Rahman \& A. Soliman. 1975. On the influence of host plants on insect resistance to bacterial diseases. Z. Angew. Entomol. 78(3): 280285.

Rogers, C. E. 1980. Biology and breeding for insect and disease resistance in oilseed crops, pp. 359-389. In M. K. Harris [ed.], Biology and breeding for resistance to arthropods and pathogens. Texas Agriculture Experiment Station Miscellaneous Publication 1451, College Station.

Rogers, C. E., T. L. Archer \& E. D. Bynum, Jr. 1984. Bacillus thuringiensis for controlling larvae of $\mathrm{Ho}$ moeosoma electellum on sunflower. J. Agric. Entomol. 1(4): 323-329.

Sabir, M. A., F. W. Sosulski \& J. A. Kernan. 1974. Phenolic constituents in sunflower flour. J. Agric. Food Chem. 22(4): 572-574.

SAS Institute. 1985. SAS user's guide: statistics, version 5 ed. SAS Institute, Cary, N.C.

Schulz, J. T. 1978. Insect pests, pp. 169-223. In J. F. Carter [ed.], Sunflower science and technology. American Society of Agronomy, Madison, Wis.

Steinly, B. A. \& M. Berenbaum. 1985. Histopathological effects of tannins on the midgut epithelium of Papilio polyxenes and P. glaucus. Entomol. Exp. Appl. 39(1): 3-9.

Vanderzant, E. S., C. D. Richardson \& S. W. Fort, Jr. 1962. Rearing of the bollworm on artificial diet. J. Econ. Entomol. 55(1): 140.

Received for publication 22 January 1990; accepted 20 June 1990 